Article

\title{
Effect of Aeration Mode on Microbial Structure and Efficiency of Treatment of TSS-Rich Wastewater from Meat Processing
}

\author{
Piotr Jachimowicz, Agnieszka Cydzik-Kwiatkowska * and Patrycja Szklarz
}

Department of Environmental Biotechnology, University of Warmia and Mazury in Olsztyn, 10-709 Olsztyn, Poland; piotr.jachimowicz@uwm.edu.pl (P.J.); patrycja.szklarz@student.uwm.edu.pl (P.S.)

* Correspondence: agnieszka.cydzik@uwm.edu.pl

Received: 26 August 2020; Accepted: 18 October 2020; Published: 22 October 2020

\begin{abstract}
The present study investigated the effect of aeration mode on microbial structure and efficiency of treatment of wastewater with a high concentration of suspended solids (TSS) from meat processing in sequencing batch reactors $(R)$. $R_{1}$ was constantly aerated, while in $R_{2}$ intermittent aeration was applied. DNA was isolated from biomass and analyzed using next-generation sequencing (NGS) and real-time PCR. As a result, in $\mathrm{R}_{1}$ aerobic granular sludge was cultivated $\left(\mathrm{SVI}_{30}=44 \mathrm{~mL} \mathrm{~g}^{-1} \mathrm{MLSS}\right)$, while in $\mathrm{R}_{2}$ a very well-settling mixture of aerobic granules and activated sludge was obtained $\left(\mathrm{SVI}_{30}=65 \mathrm{~mL} \mathrm{~g}^{-1}\right.$ MLSS). Intermittent aeration significantly increased denitrification and phosphorus removal efficiencies ( $68 \%$ vs. $43 \%, 73 \%$ vs. $65 \%$, respectively) but resulted in decomposition of extracellular polymeric substances and worse-settling properties of biomass. In both reactors, microbial structure significantly changed in time; an increase in relative abundances of Arenimonas sp., Rhodobacterace, Thauera sp., and Dokdonella sp. characterized the biomass of stable treatment of meat-processing wastewater. Constant aeration in $\mathrm{R}_{1}$ cycle favored growth of glycogen-accumulating Amaricoccus tamworthensis (10.9\%) and resulted in 2.4 times and 1.4 times greater number of ammonia-oxidizing bacteria and full-denitrifiers genes in biomass, respectively, compared to the $\mathrm{R}_{2}$.
\end{abstract}

Keywords: intermittent aeration; TSS-rich meat-processing wastewater; extracellular polymeric substances; complete denitrification; microbial structure

\section{Introduction}

The meat-processing industry uses about $24 \%$ of freshwater consumed by the food and beverage industry and up to $29 \%$ of that consumed by the agricultural sector worldwide [1]. About 341.2 million tons of meat were produced globally in year 2018 (63.9 million tons in Europe) [2]. These numbers will increase because world beef, pork, and poultry production are projected to double by 2050 [3]. Meat-processing effluents contain a lot of fats, fibers, proteins, and pathogens but also pharmaceuticals and detergents used for veterinary and cleaning activities [4]. Fats and proteins are main components of the particulate matter in meat-processing wastewater constituting on average $55.3 \%$ and $27.1 \%$ of dry mass, respectively [5]. Fat and proteins in meat industry wastewaters are usually poorly biodegradable that results in generation of odors, foam, and poor flocculation and settling of biomass that decreases the efficiency of biological processes. Oil and grease adsorb on cell surfaces lowering transfer aqueous phase and pollutant conversion rates [6].

One method that shows promise for treating this difficult-to-treat effluent is the use of granular sludge technology. Granular sludge is a self-immobilized consortium, densely packed with microorganisms used in wastewater treatment reactors [7]. The volumes of reactors with aerobic granular sludge can 
be smaller than those with activated sludge, because of very good settling properties of granules and a high concentration of microorganisms in their structure. During formation of granules microbial competition and changes in cellular metabolism occur that determine granule morphology and treatment efficiency $[8,9]$.

Granulation depends on numerous factors such as sequencing batch regimes, feeding characteristics, or organic and nitrogen loadings. The presence of aerobic, anoxic and anaerobic zones in the granule structure provides favorable conditions for the growth of both aerobic nitrifiers, and anaerobic and anoxic microorganisms. Granulation process is faster in plug-flow anaerobic feeding reactor than in fully aerobic reactor; however, the granular biomass formed in the fully aerobic configuration is more stable mostly due to better retention of nitrifying organisms favoring nitrogen removal efficiency [10]. Positive effect of anoxic or anaerobic phases in the cycle of granular sequencing batch reactor (GSBR) on nitrogen removal was also observed in other studies [11,12]. There are reports informing that aerobic granular sludge can be successfully applied to treat slaughterhouse wastewater in a lab-scale GSBR $[13,14]$, but studies connecting the efficiency of treatment with in depth analysis of structure of microbial community using next-generation sequencing (NGS) in granules are lacking.

The presence of extracellular polymeric substances (EPS) has a significant influence on the physicochemical properties of microbial biomass aggregates, including surface change, structure, flocculation, and settling properties [15]. The aeration conditions influence the production of EPS and it was observed that the content of EPS in biomass decreases under anaerobic conditions [16]. Content of carbohydrates in EPS from biomass from reactors with a high dissolved oxygen level increased with time, whereas the protein content remained unchanged [17]. The protein present in high concentrations in wastewater from meat industry can be incorporated in the bound EPS in biomass [18].

Therefore, the aim of this study was to explore interrelationships between the aeration mode, microbial community composition, and efficiency of nitrogen, phosphorus, organic compounds (COD), and total suspended solids removal in batch reactors treating wastewater from meat-processing industry with a very high concentration of suspended solids. The microbial groups involved in pollutant degradation in constantly and intermittently aerated granules treating TSS-rich meat-processing wastewater were indicated.

\section{Materials and Methods}

\subsection{Experimental Design}

Industrial wastewater (Table 1) was obtained from a meat-processing plant in Morliny (Poland) after pre-treatment in a flotation tank. During transport wastewater was stored in ice. The experiment was conducted in two batch reactors with aerobic granular sludge (GSBR) at a room temperature $\left(25^{\circ} \mathrm{C}\right)$. The reactor (Figure 1) had a height to diameter $(\mathrm{H} / \mathrm{D})$ ratio of 1.6 and a working volume of $10 \mathrm{~L}$. Volumetric exchange rate of $20 \%$ cycle $^{-1}$ and a cycle length of $6 \mathrm{~h}$ was maintained by programmable logic controllers. Air was supplied via aeration grids in the bottom of the reactors. During aeration phases, the up-flow superficial air velocity was $0.5 \mathrm{~cm} \mathrm{~s}^{-1}$ and the free dissolved oxygen concentration reached saturation. The reactors were inoculated with aerobic granular sludge (AGS) cultivated in a full-scale wastewater treatment plant in Lubawa [19]. The reactor cycle (Figure 1) consisted of $10 \mathrm{~min}$ of settling, $30 \mathrm{~min}$ of filling and decantation, and $320 \mathrm{~min}$ of reaction phase. $\mathrm{R}_{1}$ was constantly aerated, while $R_{2}$ was intermittently aerated, with $30 \mathrm{~min}$ non-aerated phases, after every $60 \mathrm{~min}$ of aeration. The operational parameters of the reactors favored formation of aerobic granules.

During reactor operation, pollutants concentration was analyzed both in the influent and the effluent. Additionally, to determine the variance of pollutant concentrations within the reactor cycle. Measurements were performed in duplicate every half hour during the period of stable reactor performance. The experiment was conducted for 200 cycles. For efficiency calculations, the technological results from the last 50 cycles of stable reactor operation were used. 
Table 1. The concentrations of pollutants in wastewater from meat processing (COD-Chemical oxygen demand; BOD—Biochemical oxygen demand; TKN—Total Kjeldahl nitrogen; TP—Total phosphorus; VFA-Volatile fatty acids).

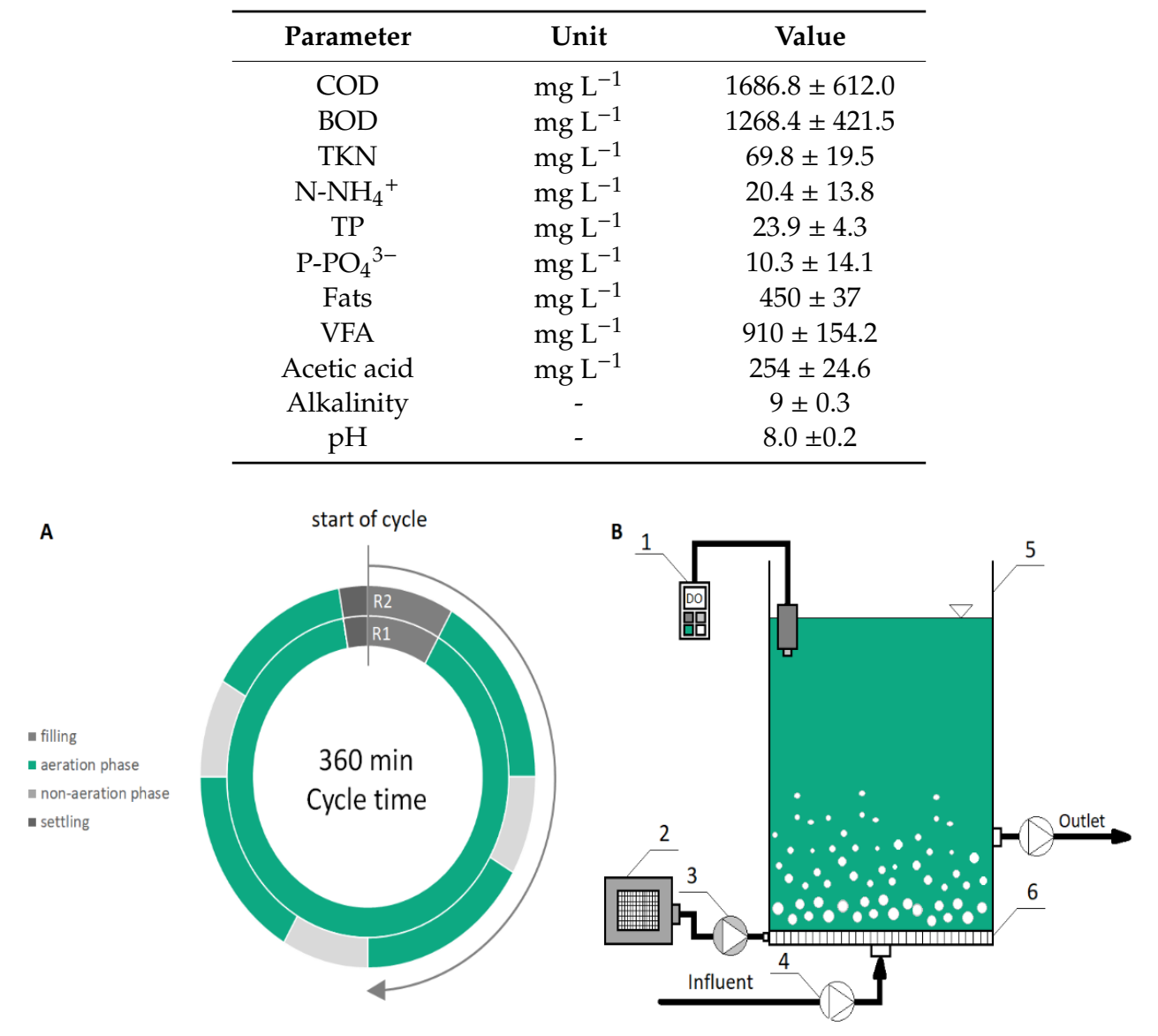

Figure 1. Organization of reactors cycle (A) and a scheme of the reactors: 1-Oxygen detector, 2-Compressor, 3-Air pump, 4-Peristaltic pump, 5-Reactor, 6-Fine bubble diffuser (B).

\subsection{Analytical Methods}

The reactors wastewater and biomass were analyzed in accordance with APHA [20]; the sludge volumetric index was measured after $30 \mathrm{~min}$ of settling $\left(\mathrm{SVI}_{30}\right)$. The oxygen concentration in the reactor was measured using a YSI ProODO ${ }^{\mathrm{TM}}$ probe (YSI). Chemical analyzes of the influent and effluent from wastewater included $\mathrm{COD}, \mathrm{BOD}, \mathrm{VFA}, \mathrm{N}-\mathrm{NH}_{4}, \mathrm{~N}-\mathrm{NO}_{2}, \mathrm{~N}-\mathrm{NO}_{3}$, and $\mathrm{P}-\mathrm{PO}_{4}$. Alkalinity, and $\mathrm{pH}$ were measured using TitroLine easy (Donserv). All analyses were conducted in triplicate.

Granule morphology and size was evaluated using wet sieving (water temperature $12{ }^{\circ} \mathrm{C}$ ) in an AS 200 screening unit (Retsch) using sieves with mesh sizes of $1 \mathrm{~mm}, 710 \mu \mathrm{m}, 500 \mu \mathrm{m}, 355 \mu \mathrm{m}, 125 \mu \mathrm{m}$, $90 \mu \mathrm{m}$ and $40 \mu \mathrm{m}$. Sieving lasted for $10 \mathrm{~min}$ with a vibration amplitude of $50 \mathrm{~mm}$.

Soluble (Sol-EPS), loosely bound (LB-EPS) and tightly bound (TB-EPS) extracellular polymeric substances (EPS) were isolated from the biomass collected from the reactors at the beginning ( $25 \mathrm{~min})$ and end (269 $\mathrm{min}$ ) of the cycle as described in Rusanowska et al. [21]. Concentration of proteins (PN) and polysaccharides (PS) in particular fractions of EPS was measured according to Frølund et al. [22], and Lowry methods, respectively.

\subsection{Next-Generation Sequencing}

For molecular analyses of the granular sludge microbiome, sludge from the two reactors was sampled at the beginning of the experiment and after 56, 128, and 164 cycles and stored at $-20^{\circ} \mathrm{C}$. DNA was isolated in triplicate using a FastDNA ${ }^{\circledR}$ SPIN kit for soil (MPBiomedicals, Irvine, CA, USA) and 
its purity and concentration was measured using a NanoDrop spectrometer (Thermo Scientific, Waltham, MA, USA). Then the DNA isolated from these three samples was pooled together for further analyses. The 939F/1492R primer set (5'-TTGACGGGGGCCCGCAC-3'/5'-TACCTTGTTACGACTT-3') was used to amplify the V6 and V8 regions of the bacterial 16S $r R N A$ gene. Sequencing of amplicons using the Illumina MiSeq platform was performed at Research and Testing Laboratory (USA). Sequencing results were deposited in the Sequence Read Archive (SRA, BioProject PRJNA613085). Depending on the sample, from 7237 to 26594 sequences were obtained (Appendix A Table A1). The sequences were analyzed bioinformatically as described in Światczak et al. [23]. To characterize microbial diversity at the species level, the Shannon-Wiener $\left(\mathrm{H}^{\prime}\right)$ index of diversity was calculated [24].

\subsection{Real-Time PCR}

Real-time PCR was performed to assess the absolute abundance of total bacteria (16S rRNA gene), ammonia-oxidizing bacteria ( $a m o A$ gene), and denitrifiers (nosZ gene) in aerobic granules. Standard curves for analysis of the copy number of the $a m o A$ and nosZ genes were constructed using a plasmid with a cloned insert (PCR product of known size) using the Clone Jet PCR cloning kit (Thermo Scientific) and freshly prepared, chemically competent Escherichia coli 109 (Promega) for cloning. In all clones the presence of the insert was confirmed by PCR with appropriate primers (Appendix A Table A1). To construct a standard curve for absolute quantification of total bacteria, DNA isolated from E. coli 109 (Promega) was used. The reaction mixture for real-time PCR contained $5 \mathrm{ng} / \mu \mathrm{L}$ of the template DNA, $10 \mu \mathrm{L}$ of Maxima SYBR Green/ROXqPCR Master Mix (2×) (Thermo Scientific, Waltham, MA, USA), primers (concentrations are given in Appendix A Table A2) and ultrapure water for a final volume of $20 \mu \mathrm{L}$. The amplification reaction began with $2 \mathrm{~min}$ at $50{ }^{\circ} \mathrm{C}$ and $10 \mathrm{~min}$ at $95^{\circ} \mathrm{C}$; then 40 cycles of amplification proceeded according to the thermal profiles given in Appendix A Table A2. Reactions were carried out in a 7500 Real-Time PCR System (Applied Biosystems) and data were analyzed with Sequence Detection Software, version 1.3 (Applied Biosystems). Reactions were normalized by adding the same amount of DNA to each reaction tube. To confirm reaction specificity, the positive and negative controls were performed. To confirm the melting temperature of PCR products, dissociation step and agarose electrophoresis in the presence of a molecular marker were performed.

\subsection{Statistics}

For statistical analysis, STATISTICA 13.1 software (StatSoft) was used. A value of $p \leq 0.05$ was defined as significant.

Normality and the homogeneity of variance were examined using the Shapiro-Wilk and the Levene's tests, respectively. If these assumptions were correct, Student's t-test was used to test the differences between the means. Technological results and abundance of microorganisms were correlated using Pearson's correlation coefficient. Links between technological parameters (cycle number and the number of anoxic phases in the reactor cycle) and microbial structure were assessed with Canonical Correspondence Analysis (CCA) with Monte Carlo permutation testing (F statistics, 499 permutations). The analyses were conducted using CANOCO for Windows ver. 5.0 and CANODRAW [25].

\section{Results and Discussion}

The obtained results indicate that in the constantly aerated reactor, aerobic granule formation was favored, whereas in the intermittently aerated reactor, a mixture of aerobic granules and activated sludge flocks was obtained. The average biomass concentration in $\mathrm{R}_{1}$ was $4.6 \pm 0.9 \mathrm{~g} \mathrm{MLSS} \mathrm{L}^{-1}$ and that in $R_{2}$ was $3.4 \pm 1.5 \mathrm{~g}$ MLSS L $^{-1}$, but the concentration of TSS in the effluent was nearly 2 times higher in $\mathrm{R}_{2}$ than in $\mathrm{R}_{1}\left(0.20 \mathrm{~g} \mathrm{~L}^{-1}\right.$ TSS vs. $\left.0.11 \mathrm{~g} \mathrm{~L}^{-1} \mathrm{TSS}\right)$. The higher concentration of biomass in $R_{2}$ may have resulted from organics being used, not for biomass growth, but for more efficient denitrification and phosphorus removal than in $\mathrm{R}_{1}$. The $\mathrm{SVI}_{30}$ was higher in $\mathrm{R}_{2}\left(65 \mathrm{~mL} \mathrm{~g}^{-1}\right.$ MLSS) than in $\mathrm{R}_{1}$ (44 $\mathrm{mL} \mathrm{g}^{-1}$ MLSS). Aerobic granules exhibit low SVI values ( $<50 \mathrm{~mL} / \mathrm{g}$ MLSS), which is in sharp contrast to activated sludge, in which SVI values exceed $120 \mathrm{~mL} / \mathrm{g}$ MLSS [9]. 
In the biomass from $R_{1}$, granules with sizes from 90 to $125 \mu \mathrm{m}$ predominated, constituting about $25.1 \%$ of the biomass, and granules with diameters over $1 \mathrm{~mm}$ were observed (Figure 2 ). In $\mathrm{R}_{2}$, about $50.0 \%$ of the biomass consisted of granules smaller than $90 \mu \mathrm{m}$. Both the superficial air velocity and the oxygen concentration affect aerobic granulation [26]. Tay et al. [27], reported that a higher shear force resulting from a higher superficial air velocity supported formation of more compact, denser, and stronger aerobic granules. The relatively low air velocity in the present experiment $\left(0.5 \mathrm{~cm} \mathrm{~s}^{-1}\right)$ and the reduced oxygen concentration in $\mathrm{R}_{2}$ worsened the settling properties of the biomass and precluded full granulation of the biomass. The size and formation of stable aerobic granules correlates with the efficiency of pollutant removal because low air velocity favors selection of slow-growing organisms [28]. In a study involving the treatment of slaughterhouse wastewater, the size of granules ranged from 0.6 to $1.2 \mathrm{~mm}$, which favored a high abundance of ammonium-oxidizing bacteria [13]. In the present study, the larger granule diameters in $\mathrm{R}_{1}$ explain the greater abundance of nitrifiers in this biomass, as indicated by amo $A$ gene analysis, and the higher nitrification rate. A study by Luo et al. [29], revealed that larger granules possess a higher microbial biodiversity than smaller granules. On the one hand, increasing granule size decreases the surface/volume ratio, resulting in a higher surface loading of pollutants, which may affect aerobic transformations in the biomass. In larger granules, the depth to which oxygen permeates will be less than in smaller granules, and larger anaerobic/anoxic zones will be present, which provide spaces for the growth of denitrifying bacteria. In contrast, in smaller granules, which have a larger surface/volume ratio, oxygen can permeate deeper than in larger granules and provide more aerobic zones for the growth of ammonia-oxidizing bacteria (AOB).

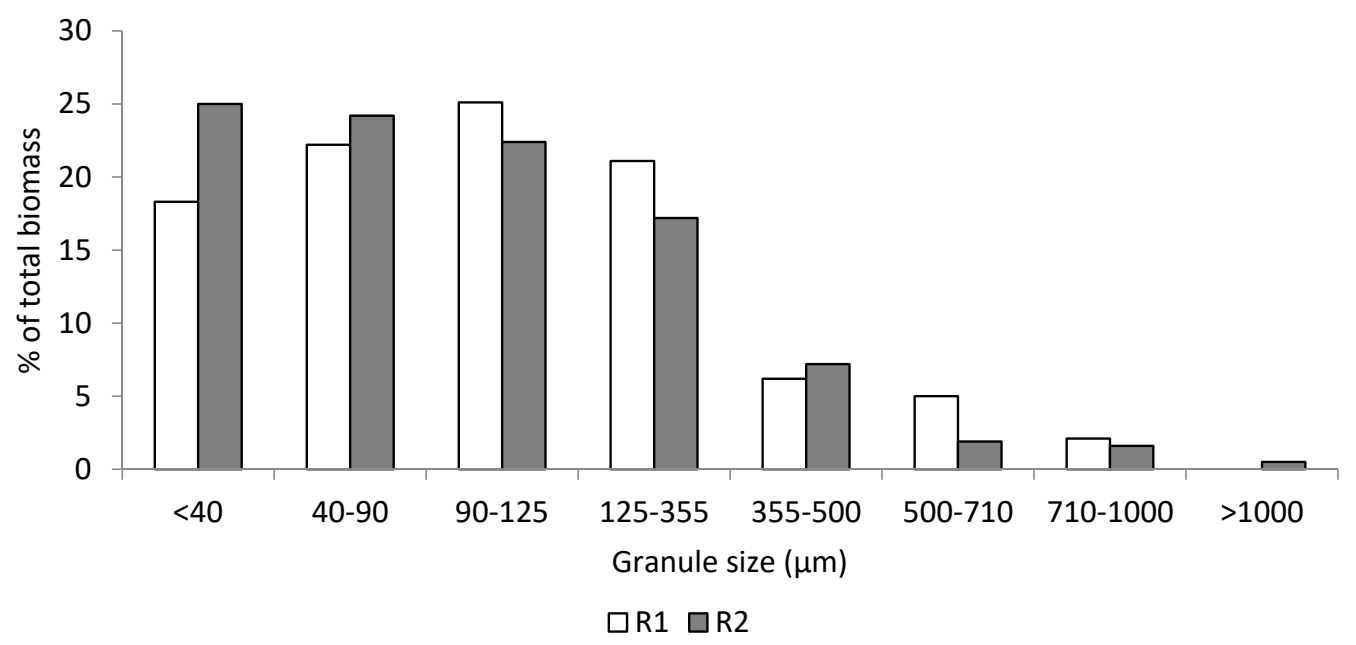

Figure 2. The distribution of granule particle sizes in the batch reactors.

In the present study, large changes in the structure of microorganisms colonizing the inoculum and biomass (Figure 3) were noted throughout the experiment. Weissbrodt et al. [30] also observed that during the granulation of activated sludge, the percentage of Competibacter sp. increased, and bacteria of the Xanthomonadaceae, Rhodospirillaceae, and Aminobacter families appeared. According to those authors, the occurrence of bacteria such as Zoogloea sp., Xanthomonadaceae, Sphingomonadales, and Rhizobiales promotes the formation of EPS, which are responsible for biomass granulation. In the present study, Dokdonella sp. were found to be responsible for the formation of EPS and denitrification in biomass. The presence of microorganisms from the above-mentioned families promotes granulation and affects the strength of the resulting granules. 


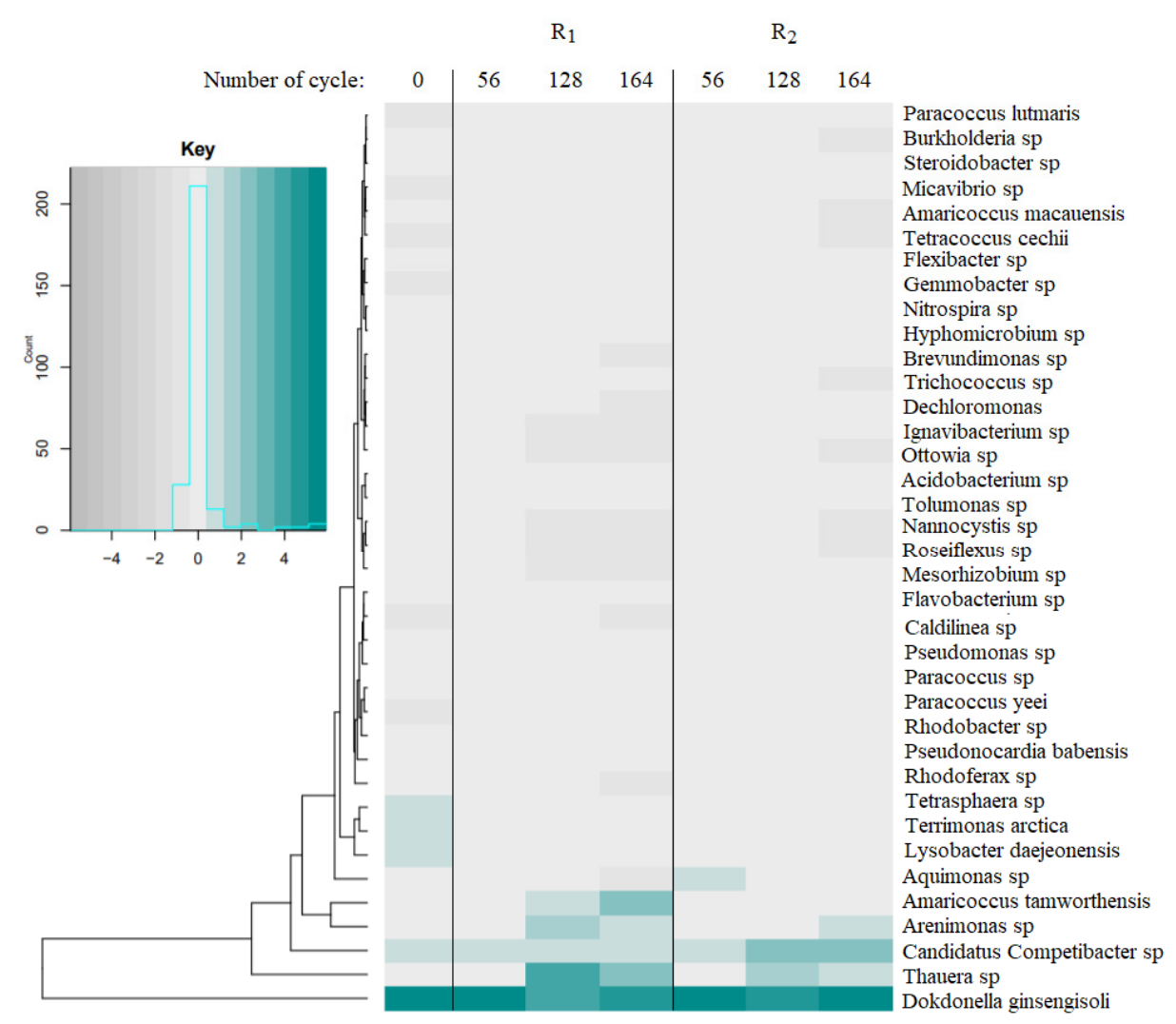

Figure 3. Heatmap of relative abundance of bacterial taxa present in aerobic granules (abundance higher that $0.5 \%$ ).

The quality of the treated wastewater in the present study indicates that systems with aerobic granules can successfully treat TSS-rich wastewater from the meat industry. Organic compounds were removed with a very high efficiency in both reactors (above 94\%). This indicates that periodic decreases in oxygen concentration during the reactor cycle, which resulted from intermittent aeration, did not reduce the efficiency of organics removal.

The average COD concentrations were $91.6 \pm 13.5 \mathrm{mg} \mathrm{L}^{-1}$ and $115.6 \pm 43.6 \mathrm{mg} \mathrm{L}^{-1}$ in the outflows from $R_{1}$ and $R_{2}$, respectively, but COD removal was more stable in $R_{1}$ (Figure 4 ). The COD removal rate was similar in both reactors $\left(197.1 \mathrm{mg}\left(\mathrm{L} \mathrm{h}^{-1}\right)\right.$ vs. $194.6 \mathrm{mg}\left(\mathrm{L} \mathrm{h}^{-1}\right)$ in $\mathrm{R}_{1}$ and $\mathrm{R}_{2}$, respectively). The carbon source that is available in wastewater affects the composition of the microbiological community. De Sousa Rollemberg et al. [31], observed that in a reactor to which acetate was dosed, microorganisms from the genera Flavobacterium (30\%), Thauera (15\%) and Aquimonas (12\%) dominated. In a reactor to which ethanol was dosed, Paracoccus sp. (36\%), Fluviicola sp. (20\%) and Sediminibacterium sp. (9\%) dominated, while addition of glucose resulted in the growth of numerous polyphosphate-accumulating organisms (PAOs) belonging to the taxa Cryomorphaceae, Rhodobacteraceae, Cytophagaceae, and Saprospiraceae. Acetate is the main source of carbon in wastewater from the meat industry, which may explain the high percentage of Thauera sp. (up to 20.1\%) in the granules in the present study. 

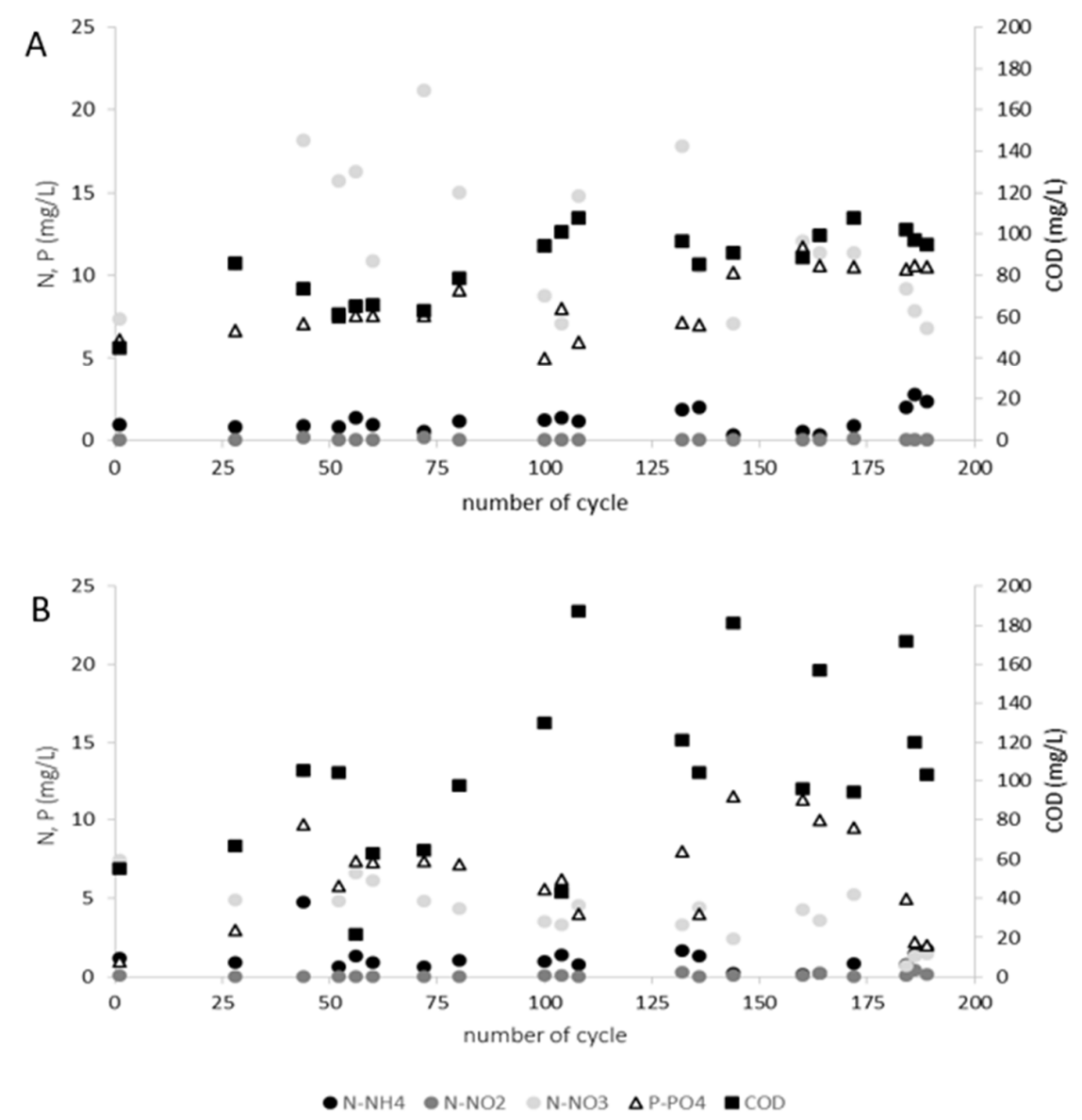

Figure 4. Changes in COD, nitrogen, and phosphorus concentrations in the effluents from the constantly aerated reactor, $\mathrm{R}_{1}(\mathrm{~A})$, and the reactor with intermittent aeration phases, $\mathrm{R}_{2}(\mathrm{~B})$.

The average $\mathrm{N}^{-\mathrm{NH}_{4}}$ concentration in each effluent was around $1 \mathrm{mg} \mathrm{L}^{-1}$ (Figure 4). The efficiencies of ammonium nitrogen removal were 82 and $86 \%$ in $R_{1}$ and $R_{2}$, respectively, which is similar to the efficiency obtained by Ersan and Erguder [32], in a granular sludge batch reactor fed with wastewater with a COD/N ratio of 15:2 and operated with anoxic phases. The concentration of $\mathrm{N}^{-\mathrm{NO}_{2}}$ in the effluents was low $\left(0.03 \pm 0.05 \mathrm{mg} \mathrm{L}^{-1}\right.$ vs. $0.12 \pm 0.12 \mathrm{mg} \mathrm{L}^{-1}$ in $\mathrm{R}_{1}$ and $\mathrm{R}_{2}$, respectively). The average concentration of $\mathrm{N}^{-\mathrm{NO}_{3}}$ in the outflow from $\mathrm{R}_{2}$ was significantly lower than that in the outflow from $\mathrm{R}_{1}\left(3.6 \pm 1.5 \mathrm{mg} \mathrm{L}^{-1}\right.$ vs. $\left.7.0 \pm 3.2 \mathrm{mg} \mathrm{L}^{-1}\right)$. Correspondingly, denitrification efficiency was higher in $\mathrm{R}_{2}$ than in $\mathrm{R}_{1}(68 \%$ vs. $43 \%)$. The environmental conditions favored the growth of aerobic denitrifiers; for example, Pseudomonas sp. and Paracoccus sp., which can increase the efficiency of denitrification under aerobic conditions, were identified in the analyzed biomass [33].

In the present study, although the overall efficiency of ammonium nitrogen removal was very similar in both reactors, the ammonium removal rate was more than three times higher in the intermittently aerated reactor $\left(9.4 \mathrm{mg} /\left(\mathrm{L} \mathrm{h}^{-1}\right)\right)$ than in the constantly aerated one $\left(3.2 \mathrm{mg} /\left(\mathrm{L} \mathrm{h}^{-1}\right)\right.$. This indicates that ammonium nitrogen oxidation is stimulated by anoxic conditions. It has been reported that increasing the number of anaerobic phases in the reactor cycle increased the total number of bacteria (as shown by abundance of $16 S$ rRNA gene), the number of AOB bacteria involved in nitrification ( $a m o A$ gene abundance) and the number of complete denitrifiers (nos $Z$ gene abundance) [34]. In the present study, such increases were not observed; however, the share of such taxa as Thauera sp., Dokdonella ginsengisoli, and Lysobacter daejeonensis, which participate in nitrogen transformations, was higher in the reactor with intermittent aeration than in the one with constant aeration. In both reactors, low concentrations of $\mathrm{N}-\mathrm{NO}_{2}$ (below $1 \mathrm{mg} \mathrm{L}^{-1}$ ) were only observed in the first hour of the cycle. In $\mathrm{R}_{1}$, the $\mathrm{N}-\mathrm{NO}_{3}$ concentration increased during the first two hours of the working cycle, 
after which it remained at a few $\mathrm{mg} \mathrm{L}^{-1}$. In $\mathrm{R}_{2}$, its concentration initially increased to $5.86 \mathrm{mg} /\left(\mathrm{L} \mathrm{h}^{-1}\right)$, and then it was removed at different rates in subsequent non-aerated phases $\left(22.5 \mathrm{mg}\left(\mathrm{L} \mathrm{h}^{-1}\right), 15.7 \mathrm{mg}\right.$ $\left(\mathrm{L} \mathrm{h}^{-1}\right)$, and $23.6 \mathrm{mg}\left(\mathrm{L} \mathrm{h}^{-1}\right)$ in phases 1, 2, and 3, respectively) (Figure 5).

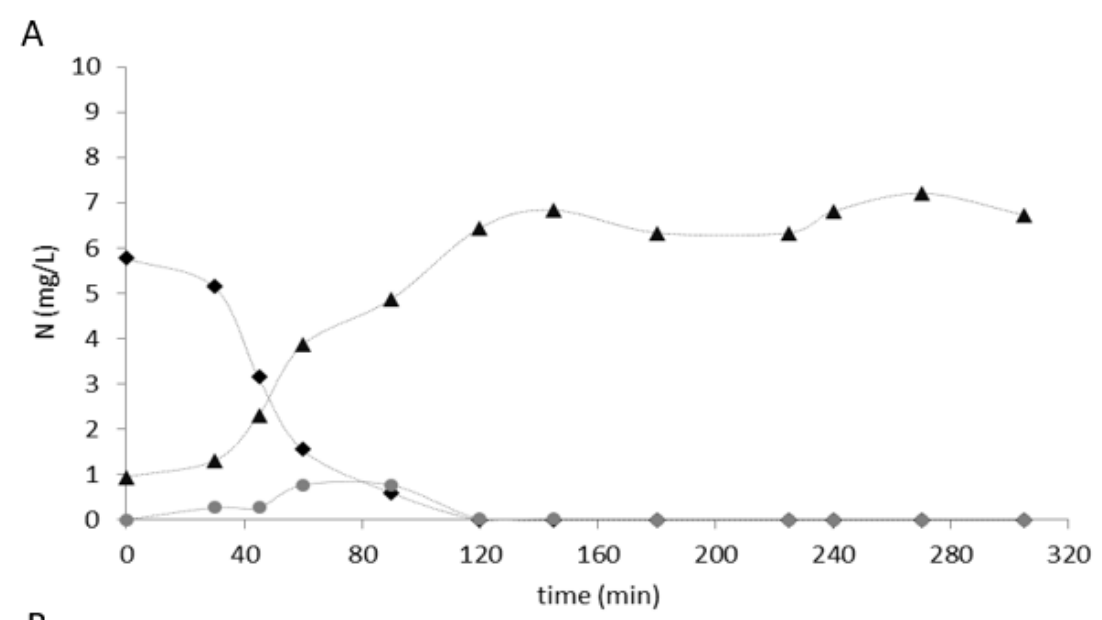

B

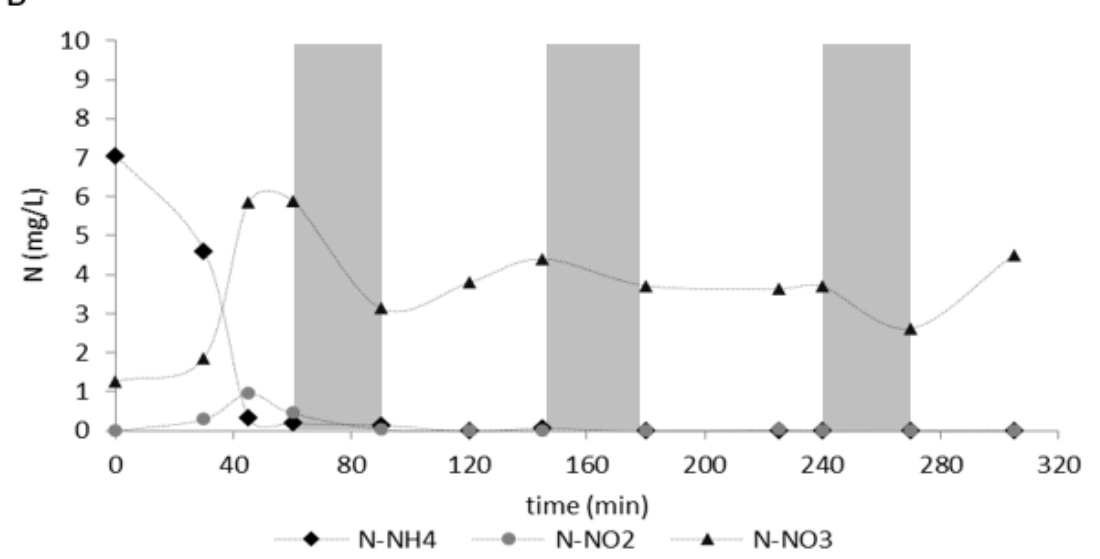

Figure 5. Concentration of ammonium, nitrite and nitrate during the cycles of $(\mathbf{A}) \mathrm{R}_{1}$ and $(\mathbf{B}) \mathrm{R}_{2}$. Gray shading indicates phases without aeration.

Due to intermittent aeration of $R_{2}$, the concentration of orthophosphates in the effluent from that reactor was significantly lower than that in the effluent from $\mathrm{R}_{1}\left(6.5 \pm 2.9 \mathrm{mg} \mathrm{L}^{-1}\right.$ vs. $8.6 \pm$ $1.7 \mathrm{mg} \mathrm{L}^{-1}$, Figure 5). As a result, the removal efficiencies were $73 \%$ and $65 \%$, respectively. A low oxygen concentration stimulates removal of $\mathrm{COD}, \mathrm{N}$ and $\mathrm{P}$ due to heterotrophic growth inside granules consisting mostly of DPAO (denitrifying PAO) [35]. It has also been reported that lower phosphorus removal performance was often observed at high dissolved oxygen (DO) concentrations of $5.0 \mathrm{mg} / \mathrm{L}$, while DO concentrations of approximately $2.5-3.0 \mathrm{mg} / \mathrm{L}$ seemed to be associated with the dominance of PAOs [36]. Taking into account the specific characteristics of wastewater from the meat industry and the lack of strict anaerobic phases, P removal was satisfactory and similar to the efficiencies obtained in other studies conducted in either constantly aerated granular batch reactors (83\%) [14].

Presence of high concentrations of volatile fatty acids (VFA) stimulates PAOs to take up VFAs anaerobically and convert them to intracellular poly- $\beta$-hydroxyalkanoates (PHAs). PAOs gain the energy and reducing power required for anaerobic VFA uptake and conversion to PHA through the hydrolysis of their intracellularly stored polyphosphate (poly-P) and glycogen [37]. In the present study, PAO belonging to Tetrasphaera sp., Arenimonas sp., and Pseudomonas sp. [38,39], were identified and their presence was much higher in $\mathrm{R}_{2}$. In $\mathrm{R}_{1}$ percentage of Amaricoccus tamworthensis gradually increased. Falvo et al. [40], point out that Amaricoccus sp. in pure culture failed to synthesize poly-P aerobically but they could synthesize glycogen aerobically, they did not assimilate either acetate or glucose 
anaerobically, and PHAs synthesis occurred aerobically but not anaerobically. Glycogen-accumulating organisms (GAOs) are a bacterial group capable of competing with PAOs for VFA in wastewater. In the present study the most numerous GAO was Candidatus Competibacter that was present in both reactors [41].

The $\mathrm{pH}$ of the effluents was 8.4 and 8.2 in $\mathrm{R}_{1}$ and $\mathrm{R}_{2}$, respectively. The wastewater $\mathrm{pH}$ is considered to be a critical factor impacting $\mathrm{N}_{2} \mathrm{O}$ emission. Hynes and Knowles [42] had pointed out that the maximum emission of $\mathrm{N}_{2} \mathrm{O}$ was observed at $\mathrm{pH} 8.5$ and decreased with decreasing $\mathrm{pH}$, which can impact of nos $Z$ gene abundance in the present study. Alkalinity of the effluent from $\mathrm{R}_{1}$ $\left(7.2 \pm 0.5 \mathrm{mval} \mathrm{L}^{-1}\right.$ ) was significantly lower than from $\mathrm{R}_{2}$ (to $8.5 \pm 0.5 \mathrm{mval} \mathrm{L}^{-1}$ ) pointing to more efficient recovery of alkalinity during denitrification in $R_{2}$ than in $R_{1}$. Even though the alkalinity was low, ammonium nitrogen was efficiently oxidized during the reactor cycle.

The distribution of EPS in the structure of granules plays an important role in improving the stability of the aerobic granular sludge and affects its SVI [43]. Extracellular polymers (EPS) were isolated from the aerobic granules at the beginning and end of the reactor cycle. The PN and PS concentrations in the three isolated EPS fractions are presented in Figure 6. In granules from $R_{1}$, content of PN and PS in Sol- and LB-EPS remained at a similar level in the GBSR cycle, but increased about 2 times at the end of the cycle in case of TB-EPS (Figure 6). In $\mathrm{R}_{2}$ a significant decrease in PN concentration in Sol- and LB-EPS was observed at the end of the cycle that was accompanied by a slight increase in PN and PS concentrations in TB-EPS (Figure 6). PN and PS are the main components of EPS in aerobic granules. For granulation, the ratio of PN to PS in EPS is more important than their quantity in a given microbiological structure [44]. A high PN/PS ratio in EPS was observed in aerobic granules with very good settling properties [45]. Decreasing the amount of PN relative to PS decreases the consistency of granules, causes problems with biomass sedimentation and increase the risk of filamentous bacteria growth and sludge bulking [46]. It has been shown that the PN/PS ratio depends on the $\mathrm{C} / \mathrm{N}$ ratio in the influent. For example, Zhang et al. [47], conducted research with $\mathrm{C} / \mathrm{N}$ ratios of 5 and 15 in the wastewater fed to reactors. At the $15 \mathrm{C} / \mathrm{N}$ ratio, which was lower than $\mathrm{C} / \mathrm{N}$ ratio used in our study (about 24), the PN/PS ratio in EPS was significantly lower than at the $5 \mathrm{C} / \mathrm{N}$ ratio, and granules with poorer settling and pollutant removal capacity were cultivated.

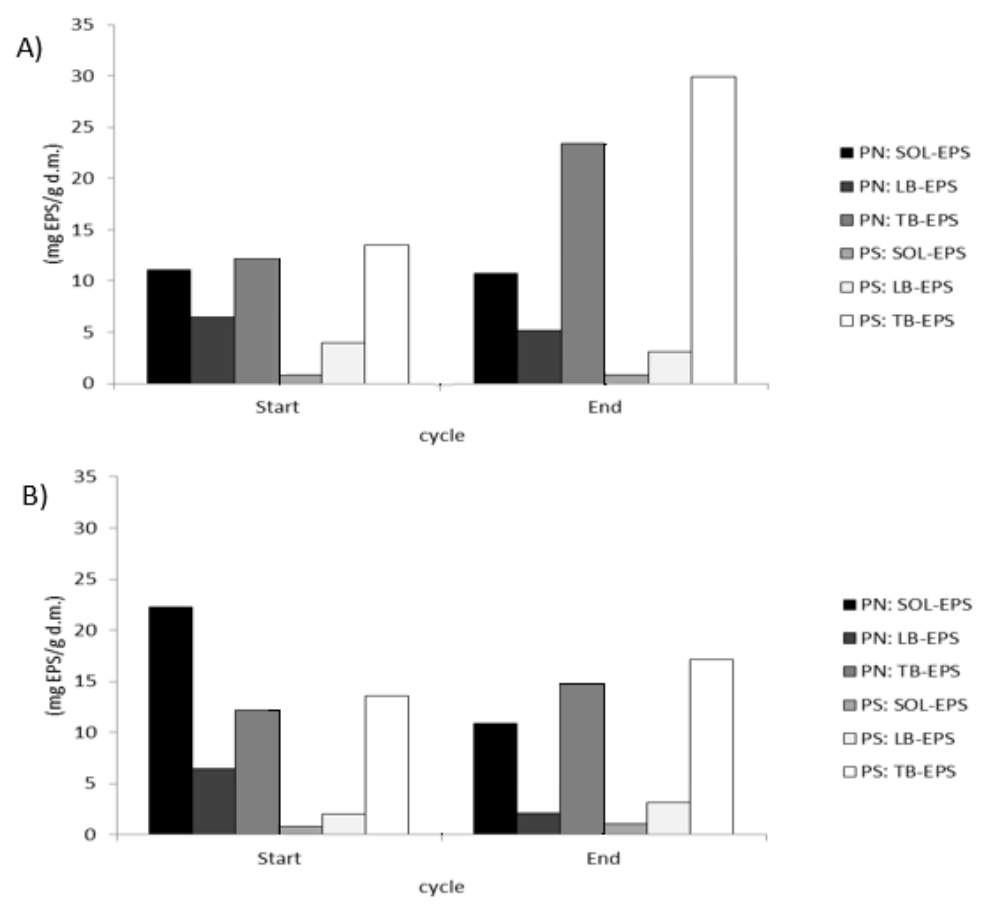

Figure 6. Content and composition of EPS in granules at the beginning and end of the reactor cycle in (A) $R_{1}$ and (B) $R_{2}$. 
In the present study, the PN/PS ratio was low and remained at around 1 in both reactors at the beginning of the cycle. The largest changes in EPS concentration took place in the TB-EPS fraction. The PN and PS concentrations in TB-EPS at the beginning of the cycle was similar in both reactors but increased more than 1.5-time in $R_{1}$ in comparison with $R_{2}$ at the end of the cycle, which explains much better settling properties of granules from $R_{1}$. Higher concentration of TB-EPS at the end of $R_{1}$ cycle can be caused by the fact that in continuously aerated reactors, microorganisms use available carbon sources mainly for biomass and EPS synthesis. In intermittently aerated reactors, in contrast, they use more of the available carbon for denitrification and phosphorus removal. Up to $50 \%$ of the EPS in aerobic granular sludge can be used in the starvation phase and anaerobic conditions [48]. The high increase in PN in TB-EPS fraction at the end of the reactor cycle was advantageous for granules stability. Both TB-EPS and LB-EPS can support the aggregation of neighboring cells in AGS formation; however, LB-EPS does not bind cells together as strongly as TB-EPS and it can be more easily destroyed, which leads to the destruction of the granule structure [49].

Real-time PCR was used to estimate the total number of bacteria (16S $r R N A$ gene copy number), the number of gene for amoA (ammonium monooxygenase gene) enzyme of AOB and full denitrifiers (nitrous oxide reductase gene nosZ) in granules during reactor operation (Figure 7). Standard curves were made showing the relationship between the $C_{t}$ threshold value and logarithm of the number of gene copies in the tested biomass. The curves were linear in the studied range of gene copy numbers, and the reactors determination coefficient was $0.99,0.98$ and 0.99 for the $16 \mathrm{~S}$ rRNA, amo $A$, and nos Z genes, respectively. The number of gene copies in the above studies was referred to $5 \mathrm{ng}$ DNA (unit of sample).

\section{A}

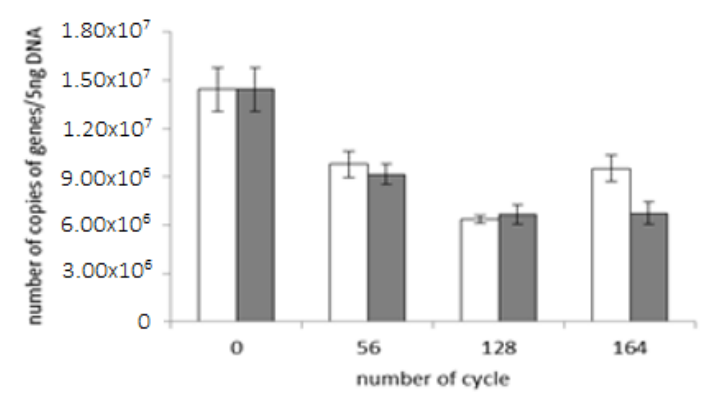

B
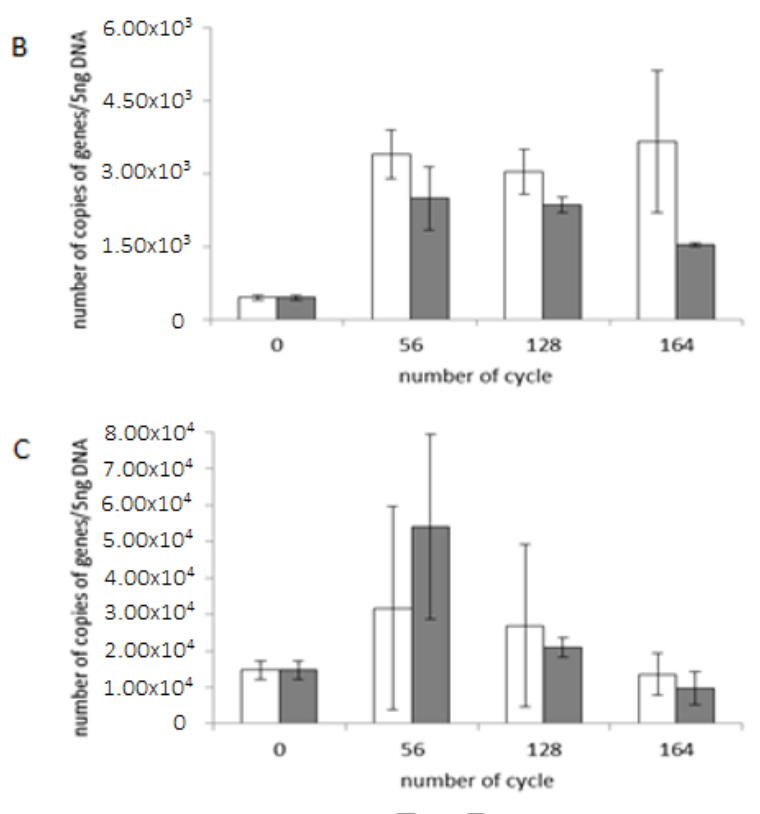

पR1 QR2

Figure 7. The absolute number of copies of (A) bacterial 16SrRNA, (B) amoA and (C) nosZ genes in the reactors. 
The abundance of the 16S rRNA genes in the biomass of both reactors gradually decreased as the experiment was carried out. The largest number of $16 \mathrm{~S}$ rRNA genes was recorded in the inoculum $\left(1.4 \times 10^{7}\right.$ copies/5 ng DNA). The number of copies of the $16 \mathrm{~S}$ rRNA in mature granules at 164 th cycle was at a level of $9.52 \times 10^{6} / 5 \mathrm{ng}$ DNA and $6.75 \times 10^{6}$ copies/5 ng DNA in $\mathrm{R}_{1}$ and $\mathrm{R}_{2}$, respectively.

The abundance of bacteria with the ammonium monooxygenase $(a m o A)$ gene in the inoculum was $4.46 \times 10^{2}$ copies $/ 5 \mathrm{ng}$ DNA. A rapid increase in the number of copies of the $a m o A$ gene was observed in $R_{1}$ at the beginning of the experiment, and during the experiment the number of copies remained in the range of 3.00-3.66 $\times 10^{3} \mathrm{copies} / 5 \mathrm{ng}$ DNA. In $\mathrm{R}_{2}$, the highest number of the investigated genes $\left(2.49 \times 10^{3}\right.$ copies $/ 5 \mathrm{ng}$ DNA $)$ was recorded in 56th cycle of experiment. At the end of the experiment, the number of ammonium monooxygenase gene in biomass from $R_{1}$ was 2.4 times higher than in $R_{2}$. The copy number of the nitrous oxide reductase (nosZ) gene in DNA isolated from the inoculum was $1.48 \times 10^{4}$ copies $/ 5 \mathrm{ng}$ DNA. In $\mathrm{R}_{1}$, the number of compiled denitrifying bacteria increased in the 56 th cycle of reactor operation to $3.17 \times 10^{4}$ copies/5 ng DNA which could improve the nosZ gene expression and lead to higher emission of $\mathrm{N}_{2}$ [46]. After that, this value slowly decreased to $1.35 \times 10^{4}$ copies $/ 5 \mathrm{ng}$ DNA (164th cycle). In $R_{2}$, the number of copies of the nos Z gene increased to $5.41 \times 10^{4}$ copies $/ 5 \mathrm{ng}$ DNA in the 56th cycle of the experiment thus the number of denitrification bacteria was $41 \%$ higher in the $R_{2}$ than in $R_{1}$. After this time, a reverse tendency was observed and at the end of the experiment the copy number of the investigated gene in biomass was about 1.4-time higher in $R_{1}$ than $R_{2}$.

Thwaites et al. [50], observed that the highest number of nitrifiers was recorded in the reactor with constant aeration but the introduction of a 60-min anaerobic phase into the working cycle lowered the number of nitrifiers while the highest number of denitrifying bacteria (nos $Z$ gene analysis) characterized biomass from a reactor with a short 20-min anaerobic phase in the cycle. The highest efficiency of nitrogen removal from wastewater was obtained in the reactor with constant aeration $(89 \%)$, while the lowest in the reactor with the initial 60-min anaerobic phase $(58 \%)$. In the presented study, a lower number of denitrification bacteria in $R_{2}$ was observed despite a higher denitrification efficiency. This may be because denitrification numbers were estimated based on the nos $Z$ gene analysis. Abundance of complete denitrifiers possessing nos $Z$ gene in biomass is favorable because ensures full conversion of nitrogen compounds to $\mathrm{N}_{2}$ and reduction in greenhouse gas emissions such as $\mathrm{NO}$ and $\mathrm{N}_{2} \mathrm{O}$ [51]. Complete denitrification can be carried out by bacteria from the genera Dokdonella, Flavobacterium, Acinetobacter, Pseudomonas, Arcobacter, and Comamonas, while microorganisms carrying out partial denitrification belong to genera Diaphorobacter, Thauera and Zoogloea [52]. In the present study, in the biomass treating wastewater from the meat industry bacteria from genera Dokdonella (Dokdonella ginsengisoli) and Thauera (Thauera sp.) predominated. Microorganisms from the genera Pseudomonas, Burkholderia (Burkholderia sp.), Geobacter, and Rhizobium were also found in the biomass from $\mathrm{R}_{2}$. These microorganisms have norB gene in their genomes, which product is responsible for the conversion of nitric oxide to nitrous oxide and can support the denitrification process. An increase in the occurrence of Paracoccus sp. was also noted at the end of the experiment in both reactors. Paracoccus sp. uses methanol as the carbon source and can denitrify at a high rate $\left(250 \mathrm{mg} \mathrm{NO}_{3} / \mathrm{g}\right.$ TSS $\mathrm{h}^{-1}$ ) $[53,54]$. The high percentage of unclassified microorganisms in $\mathrm{R}_{2}$ indicates that more variable microenvironments created in biomass by intermittent aeration favored growth of yet not classified bacteria and resulted in higher microbial biodiversity.

Bacterial consortia in aerobic granules were analyzed using NGS to draw conclusion about the relationships between their structure and aeration mode in the reactor. The total number of 118,579 $16 S$ rRNA sequence reads assigned to different operational taxonomic units was obtained by Illumina MiSeq platform (Appendix A Table A2).

To assess the within-sample complexity of microbial population, the Shannon-Wiener diversity index $\left(\mathrm{H}^{\prime}\right)$ was evaluated. The Shannon-Wiener species diversity index in inoculum was 3.67. At the final stage of the experiment the index was by about $8 \%$ higher in $R_{2}$ (3.67) compared to $R_{1}$ (3.39).

At a species level (Table 1), the most abundant in inoculum was Dokdonella ginsengisoli (19.6\%), Tetrasphaera sp. (3.8\%), Lysobacter daejeonensis (3.7\%), Terrimonas arctica (3.3\%) and Candidatus Competibacter 
(3.2\%). In $\mathrm{R}_{1}$ at the end of the experiment, biomass was dominated by Dokdonella ginsengisoli $(20.0 \%)$, Amaricoccus tamworthensis (10.9\%), Thauera sp. (10.7\%), Candidatus Competibacter sp. $(5.1 \%)$ and Arenimonas sp. (4.1\%). Dokdonella ginsengisoli (16.0\%), Candidatus Competibacter (7.7\%), Arenimonas sp. (2.5\%) and Thauera sp. $(2.4 \%)$ dominated also at the end of the experiment in $\mathrm{R}_{2}$.

During the experiment disappearance or reduction of the percentage was observed for Acidobacterium sp., Tetrasphaera sp., Terrimonas arctica, Roseiflexus sp., Ignavibacterium sp., Ottowia sp., Rhodoferax sp., Nannocystis sp., Tolumonas sp., Aquimonas sp. and Lysobacter daejeonensis.

In the present research, large changes in the structure of microorganisms colonizing the inoculum and granular sludge were noted throughout the experiment. Weissbrodt et al. [30], observed that during the granulation of activated sludge the percentage of Competibacter sp. increased and bacteria of the Xanthomonadaceae, Rhodospirillaceae, and Aminobacter family appeared. According to the authors, occurrence of such bacteria as Zoogloea sp., Xanthomonadaceae, Sphingomonadales, and Rhizobiales promotes the formation of EPS that are responsible for biomass granulation. In the present study, Xanthomonadaceae (Dokdonella ginsengisoli, Lysobacter daejeonensis) were found to be responsible for the formation of EPS and denitrification in biomass. The presence of microorganisms from the above-mentioned families promotes granulation and affects the strength of the resulting granules.

Bacterial taxa unique for the biomass from $\mathrm{R}_{1}$ were identified including e.g., Pseudonocardia babensis, Amaricoccus tamworthensis, Paracoccus sp., Paracoccus yeei, Arenimonas sp. Many environmental bacteria isolated, among others, from water and soil possess the ability to break down fats, oils and greases [55]. The presence of complex compounds such as proteins, lipids or polysaccharides in wastewater stimulates growth of microorganisms in the biomass that carry out the hydrolysis of complex organic compounds, e.g., Sphingobacteriales, Chitinophagaceae, or Flavobacterium sp., which were also observed in the presented studies. In the granules, Burkholderia sp., and Pseudomonas sp. have been also identified that can break down lipids to fatty acids [56,57]. In the structure of aerobic granules, lipids occur peripherally in EPS, thus, the fats in the influent may attach to the surface of the granules and impede the transfer of oxygen deep into its structure increasing the demand of oxygen for microorganisms [58].

The ordination diagram (Figure 8) shows that at the level of the species variable aeration conditions in the reactor cycle did not affect the composition of microbiota $(p=0.18, \mathrm{~F}=1.66)$, while the number of reactor working cycles significantly affected it $(p<0.01, \mathrm{~F}=3.61)$. There was a strong positive correlation between the percentage share in the biomass of Gemmobacter sp. $(\mathrm{R}=0.98)$, Flexibacter sp. $(\mathrm{R}=0.96)$, Paracoccus yeei $(\mathrm{R}=0.85)$ and Rhodobacter $\mathrm{sp} .(\mathrm{R}=0.97)$ and the experimental cycle indicating that these taxa were important for efficient treatment of meat-processing wastewater. A negative correlation was observed, among others, for Ignavibacterium sp. $(\mathrm{R}=-0.96)$, Roseiflexus sp. $(\mathrm{R}=-0.94)$ and Tolumonas sp. $(\mathrm{R}=-0.92)$. 


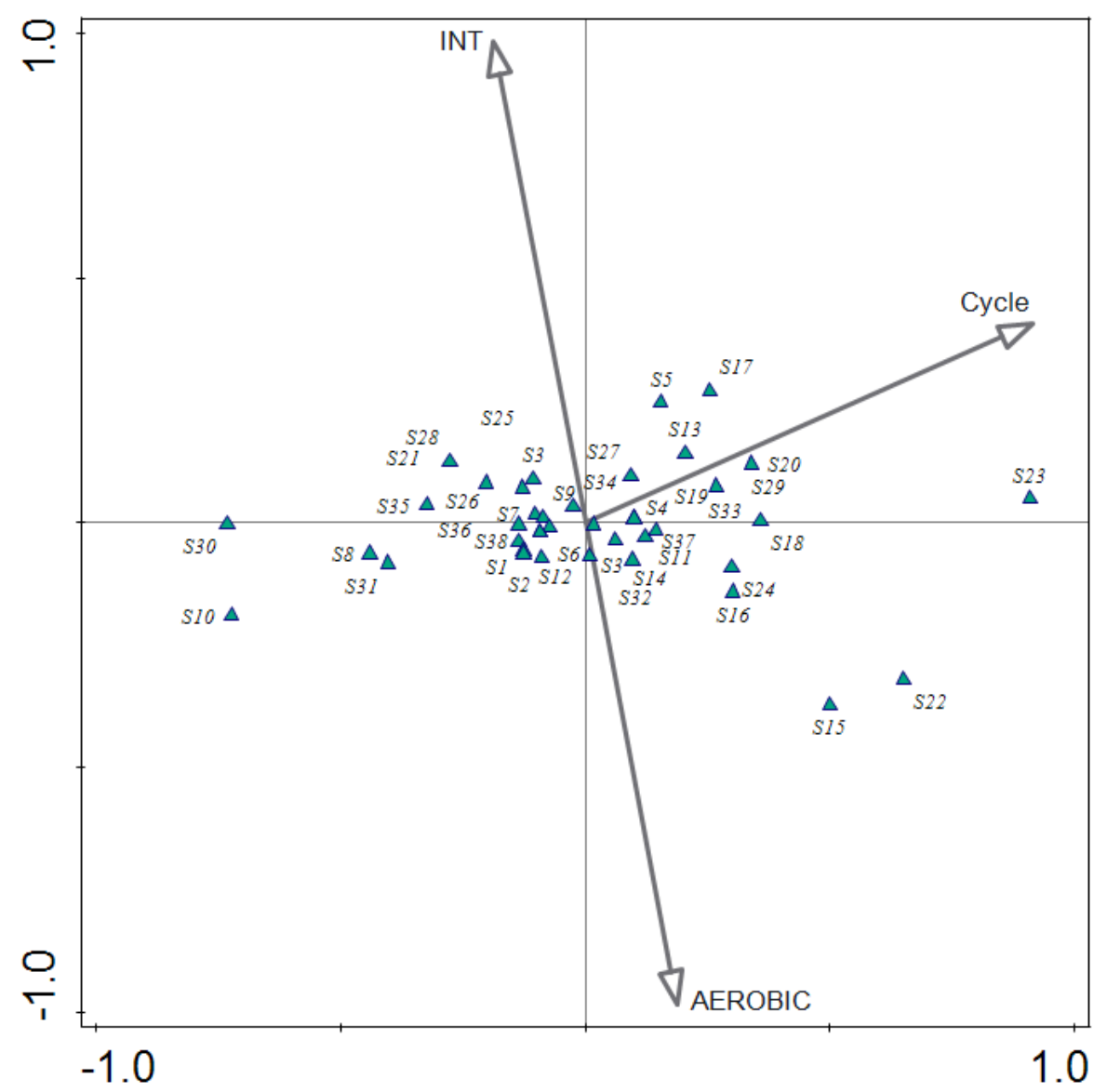

Figure 8. CCA of community of bacteria in the reactors. Environmental variables are represented by grey arrows (Cycle-Number of the reactor cycles, AEROBIC - Constant aeration in the reactor cycle, INT-intermittent aeration in the rector cycle). The taxa are named by letters and numbers: Acidobacterium sp. (S1), Tetrasphaera sp. (S2), Pseudonocardia babensis (S3), Flexibacter sp. (S4), Flavobacterium sp. (S5), Terrimonas arctica (S6), Caldilinea sp. (S7), Roseiflexus sp. (S8), Trichococcus sp. (S9), Ignavibacterium sp. (S10), Nitrospira sp. (S11), Breoundimonas sp. (S12), Hyphomicrobium sp. (S13), Mesorhizobium sp. (S14), Amaricoccus macauensis (S15), Amaricoccus tamworthensis (S16), Gemmobacter sp. (S17), Paracoccus lutimaris (S18), Paracoccus sp. (S19), Paracoccus yeei (S20), Rhodobacter sp. (S21), Tetracoccus cechii (S22), Micavibrio sp. (S23), Burkholderia sp. (S24), Hydrogenophaga sp. (S25), Ottowia sp. (S26), Rhodoferax sp. (S27), Dechloromonas sp. (S28), Thauera sp. (S29), Nannocystis sp. (S30), Tolumonas sp. (S31), Steroidobacter sp. (S32), Pseudomonas sp. (S33), Candidatus Competibacter (S34), Aquimonas sp. (S35), Dokdonella ginsengisoli (S36), Arenimonas sp. (S37), Lysobacter daejeonensis (S38).

\section{Conclusions}

The research allowed to draw the following conclusions:

- In an intermittently aerated reactor fed with high-TSS wastewater from meat industry higher N and $P$ removal and a higher concentration of biomass was observed, but also a higher concentration of suspended solids in treated wastewater, smaller diameters of granules and deteriorated settling properties of biomass mainly as a result of the reduction of EPS content in biomass was noted;

- CCA analysis showed that microbial structure significantly changed in time; an increase in abundances of Arenimonas sp., Thauera sp., and Dokdonella sp. characterized mature granules in period of stable treatment of meat-processing wastewater;

- Constant aeration in the cycle increases the number of nitrifying and denitrifying genes in biomass (amo $A$ and nos $\mathrm{Z}$ analysis) while intermittent aeration increases microbial diversity of granules; 
- Constant aeration favored growth of microorganisms from the Rhodanobacteraceae, Rhodobacteraceae and Xanthomonadaceae families while in intermittently aerated reactors Competibacteraceae family was more abundant $(7.8 \%)$ and appeared.

Author Contributions: Conceptualization, P.J., and A.C.-K.; methodology, P.J. and A.C.-K.; software, P.J.; validation, P.J.; formal analysis, P.J., and A.C.-K.; investigation, P.J., and P.S.; resources, P.J.; data curation, P.J., and A.C.-K.; writing-Original draft preparation, P.J.; writing—Review and editing, A.C.-K. and P.S.; visualization, P.J.; supervision, A.C.-K.; project administration, P.J.; funding acquisition, A.C.-K. All authors have read and agreed to the published version of the manuscript.

Funding: This research was funded by Minister of Science and Higher Education grant number 010/RID/2018/19 and Development Program at the University of Warmia and Mazury in Olsztyn grant number POWR.03.05. 00-00-Z310/17.

Acknowledgments: Project financially supported by Minister of Science and Higher Education in the range of the program entitled "Regional Initiative of Excellence" for the years 2019-2022, Project No. 010/RID/2018/19, amount of funding 12,000,000 PLN and was written as a result of the author's internship in Aalborg University, Denmark, co-financed by the European Union under the European Social Fund (Operational Program Knowledge Education Development), carried out in the project Development Program at the University of Warmia and Mazury in Olsztyn (POWR.03.05. 00-00-Z310/17).

Conflicts of Interest: The authors declare no conflict of interest.

\section{Appendix A}

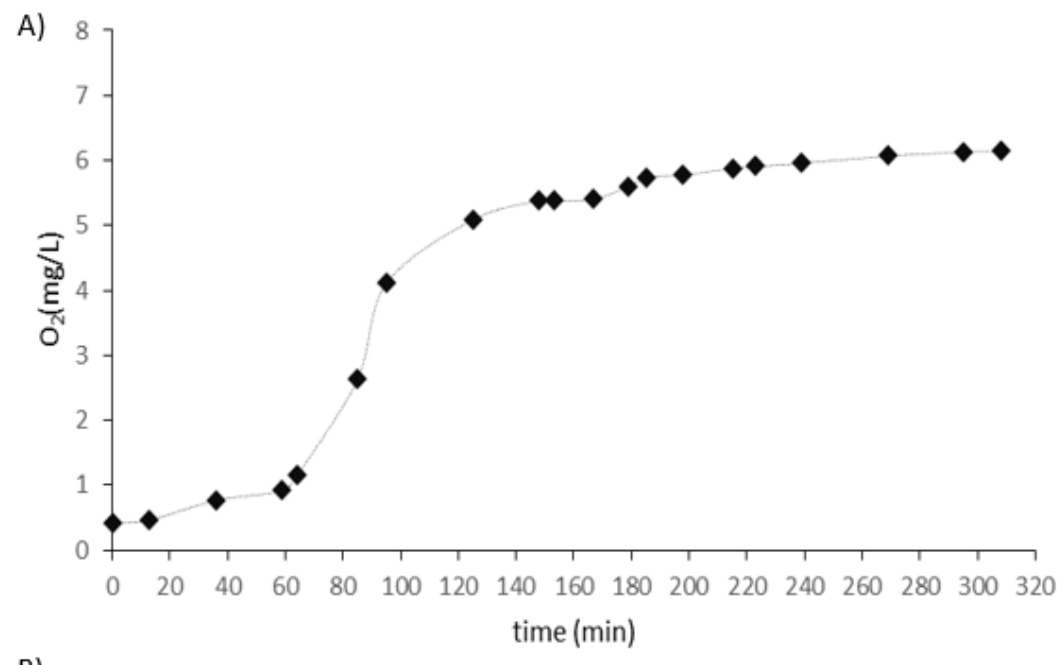

B)

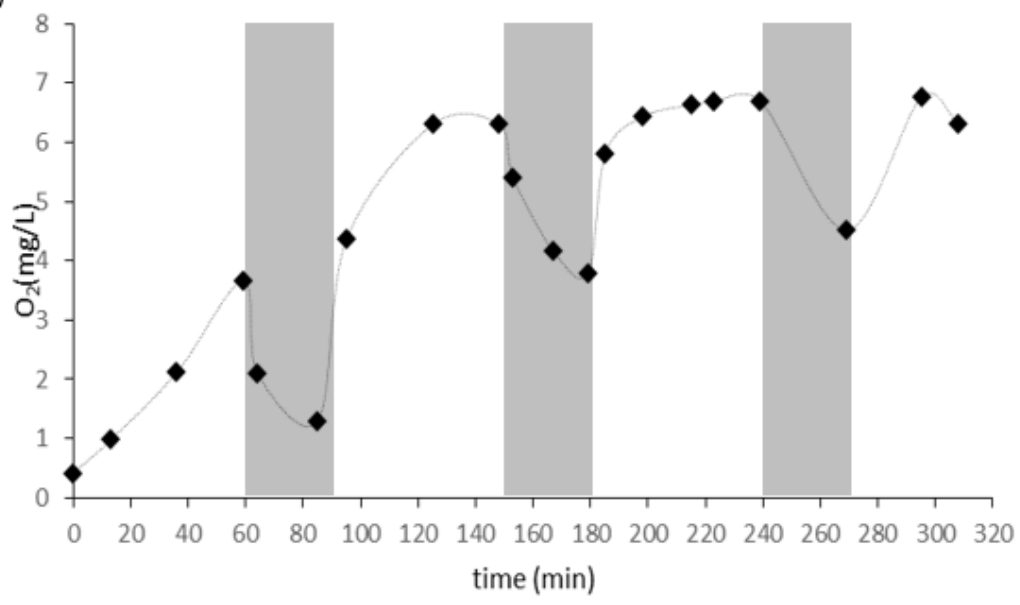

Figure A1. Changes of oxygen concentration in reactors cycle in (A) reactor $R_{1}$ and $(B) R_{2}$. Gray shading indicates phases without aeration. 
Table A1. Primers and conditions applied in real-time PCR.

\begin{tabular}{|c|c|c|c|c|}
\hline Gene, Primer & $\begin{array}{c}\text { Primer } \\
\text { Concentration }\end{array}$ & $\begin{array}{c}\text { Size of } \\
\text { Amplicon (bp) }\end{array}$ & Thermal Profile & Reference \\
\hline $\begin{array}{c}a m o A \\
\text { (amoA1Fa/amoA2R) }\end{array}$ & $100 \mathrm{nM}$ & $\sim 500$ & $\begin{array}{c}94{ }^{\circ} \mathrm{C} / 15 \mathrm{~s}, 52{ }^{\circ} \mathrm{C} / 45 \mathrm{~s}, \\
60^{\circ} \mathrm{C} / 45 \mathrm{~s}\end{array}$ & [59] \\
\hline $\begin{array}{l}\text { Bacterial 16S rRNA } \\
\quad(519 \mathrm{~F} / 907 \mathrm{R})\end{array}$ & $100 \mathrm{nM}$ & $\sim 600$ & $\begin{array}{c}94^{\circ} \mathrm{C} / 15 \mathrm{~s}, 50{ }^{\circ} \mathrm{C} / 40 \mathrm{~s}, \\
60{ }^{\circ} \mathrm{C}, 40 \mathrm{~s}\end{array}$ & [60] \\
\hline $\begin{array}{c}\text { nosZ } \\
\text { (NosZ-F/NosZ1622R) }\end{array}$ & $200 \mathrm{nM}$ & $\sim 500$ & $\begin{array}{c}94^{\circ} \mathrm{C} / 15 \mathrm{~s}, 60^{\circ} \mathrm{C} / 2.5 \\
\min \end{array}$ & {$[61,62]$} \\
\hline
\end{tabular}

Table A2. Diversity indices from aerobic granular sludge sample in reactorss.

\begin{tabular}{ccccc}
\hline Reactor & Number of Cycle & $\begin{array}{c}\text { Number of } \\
\text { Sequences }\end{array}$ & $\begin{array}{c}\text { Number of } \\
\text { OTU }\end{array}$ & $\begin{array}{c}\text { Shannon-Wiener } \\
\text { Index (H') }\end{array}$ \\
\hline Inoculum & 0 & 9675 & 994 & 3.67 \\
\hline \multirow{2}{*}{$\mathrm{R}_{1}$} & 56 & 20,360 & 873 & 3.22 \\
& 128 & 18,336 & 654 & 2.26 \\
$\mathrm{R}_{2}$ & 164 & 26,594 & 901 & 3.39 \\
\hline & 126 & 21,699 & 947 & 3.02 \\
& 164 & 7237 & 740 & 3.59 \\
\hline
\end{tabular}

\section{References}

1. Gerbens-Leenes, P.W.; Mekonnen, M.M.; Hoekstra, A.Y. The water footprint of poultry, pork and beef: A comparative study in different countries and production systems. Water Resour. Ind. 2013, 1-2, 25-36. [CrossRef]

2. The Food and Agriculture Organization. Available online: http://www.fao.org/faostat/en (accessed on 1 August 2020).

3. Pingali, P. Westernization of Asian diets and the transformation of food systems: Implications for research and policy. Food Policy 2007, 32, 281-298. [CrossRef]

4. Bustillo-Lecompte, C.F.; Mehrvar, M.; Quinones-Bolanos, E. Cost-effectiveness analysis of TOC removal from slaughterhouse wastewater using combined anaerobic-aerobic and $\mathrm{UV} / \mathrm{H}_{2} \mathrm{O}_{2}$ processes. J. Environ. Manag. 2014, 134, 145-152. [CrossRef] [PubMed]

5. Kiepper, B.H.; Merka, W.C.; Fletcher, D.L. Proximate composition of poultry processing wastewater particulate matter from broiler slaughter plants. Poult. Sci. 2008, 87, 1633-1636. [CrossRef]

6. Cammarota, M.C.; Freire, D.G. A review on hydrolytic enzymes in the treatment of wastewater with high oil and grease content. Bioresour. Technol. 2006, 97, 2195-2210. [CrossRef] [PubMed]

7. Gao, D.; Liu, L.; Liang, H.; Wu, W.M. Aerobic granular sludge: Characterization, mechanism of granulation and application to wastewater treatment. Crit. Rev. Biotechnol. 2011, 31, 137-152. [CrossRef] [PubMed]

8. Liu, Y.; Yang, S.F.; Tay, J.H. Improved stability of aerobic granules by selecting slow-growing nitrifying bacteria. J. Biotechnol. 2004, 108, 161-169. [CrossRef] [PubMed]

9. Cydzik-Kwiatkowska, A.; Zielińska, M. Bacterial communities in full-scale wastewater treatment systems. World J. Microbiol. Biotechnol. 2016, 32, 66. [CrossRef] [PubMed]

10. Carrera, P.; Campo, R.; Méndez, R.; Di Bella, G.; Campos, J.L.; Mosquera-Corral, A.; Val del Río, A. Does the feeding strategy enhance the aerobic granular sludge stability treating saline effluents? Chemosphere 2019, 226, 865-873. [CrossRef] [PubMed]

11. Chen, F.Y.; Liu, Y.Q.; Tay, J.H.; Ning, P. Alternating anoxic/oxic condition combined with step-feeding mode for nitrogen removal in granular sequencing batch reactors (GSBRs). Sep. Purif. Technol. 2013, 105, 63-68. [CrossRef] 
12. Cydzik-Kwiatkowska, A.; Wojnowska-Baryła, I. Nitrogen-converting communities in aerobic granules at different hydraulic retention times (HRTs) and operational modes. World J. Microbiol. Biotechnol. 2015, 31, 75-83. [CrossRef] [PubMed]

13. Liu, Y.; Kang, X.; Li, X.; Yuan, Y. Performance of aerobic granular sludge in a sequencing batch bioreactor for slaughterhouse wastewater treatment. Bioresour. Technol. 2015, 190, 487-491. [CrossRef] [PubMed]

14. Cassidy, D.P.; Belia, E. Nitrogen and phosphorus removal from an abattoir wastewater in a SBR with aerobic granular sludge. Water Res. 2005, 39, 4817-4823. [CrossRef] [PubMed]

15. Wingender, J.; Neu, T.R.; Flemming, H.C. (Eds.) Microbial Extracellular Polymeric Substances: Characterization, Structures and Function; Springer: Berlin/Heidelberg, Germany, 1999; pp. 1-18.

16. Sheng, G.P.; Yu, H.Q.; Li, X.Y. Extracellular polymeric substances (EPS) of microbial aggregates in biological wastewater treatment systems: A review. Biotechnol. Adv. 2010, 28, 882-894. [CrossRef] [PubMed]

17. Shin, H.S.; Kang, S.T.; Nam, S.Y. Effect of carbohydrate and protein in the EPS on sludge settling characteristics. Water Sci. Technol. 2001, 43, 193-196. [CrossRef]

18. Sponza, D.T. Investigation of extracellular polymer substances (EPS) and physicochemical properties of different activated sludge flocs under steady-state conditions. Enzym. Microb. Technol. 2003, 32, 375-385. [CrossRef]

19. Świątczak, P.; Cydzik-Kwiatkowska, A. Performance and microbial characteristics of biomass in a full-scale aerobic granular sludge wastewater treatment plant. Environ. Sci. Pollut. 2017, 25, 1655-1669. [CrossRef]

20. APHA (Ed.) 1992 Standard Methods for the Examination of Water and Wastewater, 18th ed.; APHA: Washington, DC, USA, 1992.

21. Rusanowska, P.; Cydzik-Kwiatkowska, A.; Świątczak, P.; Wojnowska-Baryła, I. Changes in extracellular polymeric substances (EPS) content and composition in aerobic granule size-fractions during reactor cycles at different organic loads. Bioresour. Technol. 2019, 272, 188-193. [CrossRef]

22. Frølund, B.; Griebe, T.; Nielsen, P.H. Enzymatic activity in the activated-sludge floc matrix. Appl. Microbiol. Biotechnol. 1995, 43, 755-761. [CrossRef]

23. Świątczak, P.; Cydzik-Kwiatkowska, A.; Rusanowska, P. Microbiota of anaerobic digesters in a full-scale wastewater treatment plant. Arch. Environ. Prot. 2017, 43, 53-60. [CrossRef]

24. Hill, M.O. Diversity and evenness: A unifying notation and its consequences. Ecology 1973, 54, 427-432. [CrossRef]

25. Ter Braak, C.J.F.; Šmilauer, P. Canoco 5: Software for multivariate data exploration, testing and summarization. In Biometrics; Plant Research International: Wageningen, The Netherlands, 2012.

26. Mosquera-Corral, A.; De Kreuk, M.K.; Heijnen, J.J.; Van Loosdrecht, M.C. Effects of oxygen concentration on $\mathrm{N}$-removal in an aerobic granular sludge reactor. Water Res. 2005, 39, 2676-2686. [CrossRef] [PubMed]

27. Tay, J.H.; Liu, Q.S.; Liu, Y. The effect of upflow air velocity on the structure of aerobic granules cultivated in a sequencing batch reactor. Water Sci. Technol. 2004, 49, 35-40. [CrossRef]

28. De Kreuk, M.K.; Pronk, M.; Van Loosdrecht, M.C. Formation of aerobic granules and conversion processes in an aerobic granular sludge reactor at moderate and low temperatures. Water Res. 2005, 39, 4476-4484. [CrossRef]

29. Luo, J.; Chen, H.; Han, X.; Sun, Y.; Yuan, Z.; Guo, J. Microbial community structure and biodiversity of size-fractionated granules in a partial nitritation-anammox process. FEMS Microbiol. Ecol. 2005, 93, fix021. [CrossRef]

30. Weissbrodt, D.G.; Neu, T.R.; Kuhlicke, U.; Rappaz, Y.; Holliger, C. Assessment of bacterial and structural dynamics in aerobic granular biofilms. Front. Microbiol. 2013, 4, 175. [CrossRef]

31. De Sousa Rollemberg, S.; De Oliveira, L.; Barros, A.; Melo, V.; Firmino, P.; Dos Santos, A. Effects of carbon source on the formation, stability, bioactivity and biodiversity of the aerobic granule sludge. Bioresour. Technol. 2019, 278, 195-204. [CrossRef]

32. Erşan, Y.Ç.; Erguder, T.H. The effect of seed sludge type on aerobic granulation via anoxic-aerobic operation. Environ. Technol. 2014, 35, 2928-2939. [CrossRef]

33. Ji, B.; Yang, K.; Zhu, L.; Jiang, Y.; Wang, H.; Zhou, J.; Zhang, H. Aerobic denitrification: A review of important advances of the last 30 years. Biotechnol. Bioprocess Eng. 2015, 20, 643-651. [CrossRef]

34. Cydzik-Kwiatkowska, A.; Rusanowska, P.; Zielińska, M.; Bernat, K.; Wojnowska-Baryła, I. Microbial structure and nitrogen compound conversions in aerobic granular sludge reactors with non-aeration phases and acetate pulse feeding. Environ. Sci. Pollut. Res. 2016, 23, 24857-24870. [CrossRef] [PubMed] 
35. Griffiths, P.C.; Stratton, H.M.; Seviour, R.J. Environmental factors contributing to 385 the "G bacteria" population in full-scale EBPR plants. Water Sci. Technol. 2002, 4-5, 185-192. [CrossRef]

36. Zeng, R.J.; Yuan, Z.; Keller, J. Improved understanding of the interactions and complexities of biological nitrogen and phosphorus removal processes. Rev. Environ. Sci. Biol. 2004, 3, 265-272. [CrossRef]

37. Nielsen, P.H.; Mielczarek, A.T.; Kragelund, C. A conceptual ecosystem model of microbial communities in enhanced biological phosphorus removal plants. Water Res. 2010, 44, 5070-5088. [CrossRef] [PubMed]

38. Ge, H.; Batstone, D.J.; Keller, J. Biological phosphorus removal from abattoir wastewater at very short sludge ages mediated by novel PAO clade Comamonadaceae. Water Res. 2015, 69, 173-182. [CrossRef] [PubMed]

39. Mandel, A.; Zekker, I.; Jaagura, M.; Tenno, T. Enhancement of anoxic phosphorus uptake of denitrifying phosphorus removal process by biomass adaption. Int. J. Environ. Sci. Technol. 2019, 16, 5965-5978. [CrossRef]

40. Falvo, A.; Levantesi, C.; Rossetti, S.; Seviour, R.J.; Tandoi, V. Synthesis of intracellular storage polymers by Amaricoccus kaplicensis, a tetrad forming bacterium present in activated sludge. J. Appl. Microbiol. 2001, 91, 299-305. [CrossRef] [PubMed]

41. Saunders, A.M.; Oehmen, A.; Blackall, L.L. The effect of GAOs (glycogen accumulating organisms) on anaerobic carbon requirements in full-scale Australian EBPR (enhanced biologicalphosphorus removal) plants. Water Sci. Technol. 2003, 47,37-43. [CrossRef] [PubMed]

42. Hynes, R.K.; Knowles, R. Production of nitrous oxide by Nitrosomonas europaea: Effects of acetylene, $\mathrm{pH}$, and oxygen. Can. J. Microbiol. 1984, 30, 1397-1404. [CrossRef]

43. Wang, Z.P.; Liu, L.L.; Yao, H.; Cai, W.M. Effects of extracellular polymeric substances on aerobic granulation in sequencing batch reactors. Chemosphere 2006, 63, 1728-1735. [CrossRef]

44. Al-Halbouni, D.; Traber, J.; Lyko, S.; Wintgens, T.; Melin, T.; Tacke, D.; Hollender, J. Correlation of EPS content in activated sludge at different sludge retention times with membrane fouling phenomena. Water Res. 2008, 42, 1475-1488. [CrossRef]

45. McSwain, B.S.; Irvine, R.L.; Hausner, M.; Wilderer, P.A. Composition and distribution of extracellular polymeric substances in aerobic flocs and granular sludge. Appl. Environ. Microbiol. 2005, 71, 1051-1057. [CrossRef] [PubMed]

46. Adav, S.S.; Lee, D.J.; Tay, J.H. Extracellular polymeric substances and structural stability of aerobic granule. Water Res. 2008, 42, 1644-1650. [CrossRef] [PubMed]

47. Zhang, H.; Jia, Y.; Khanal, S.K.; Lu, H.; Fang, H.; Zhao, Q. Understanding the role of extracellular polymeric substances on ciprofloxacin adsorption in aerobic sludge, anaerobic sludge, and sulfate-reducing bacteria sludge systems. Environ. Sci. Technol. 2018, 52, 6476-6486. [CrossRef] [PubMed]

48. Wang, Y.X.; Lu, Z.X. Optimization of processing parameters for the mycelial growth and extracellular polysaccharide production by Boletus spp. ACCC 50328. Process Biochem. 2005, 40, 1043-1051. [CrossRef]

49. Chen, H.; Zhou, S.; Li, T. Impact of extracellular polymeric substances on the settlement ability of aerobic granular sludge. Environ. Technol. 2010, 31, 1601-1612. [CrossRef] [PubMed]

50. Thwaites, B.J.; Reeve, P.; Dinesh, N.; Short, M.D.; van den Akker, B. Comparison of an anaerobic feed and split anaerobic-aerobic feed on granular sludge development, performance and ecology. Chemosphere 2017, 172, 408-417. [CrossRef]

51. Jones, C.M.; Stres, B.; Rosenquist, M.; Hallin, S. Phylogenetic analysis of nitrite, nitric oxide, and nitrous oxide respiratory enzymes reveal a complex evolutionary history for denitrification. Mol. Biol. Evol. 2008, 25, 1955-1966. [CrossRef] [PubMed]

52. Pishgar, R.; Dominic, J.A.; Sheng, Z.; Tay, J.H. Denitrification performance and microbial versatility in response to different selection pressures. Bioresour. Technol. 2019, 281, 72-83. [CrossRef]

53. Srinandan, C.S.; Jadav, V.; Cecilia, D.; Nerurkar, A.S. Nutrients determine the spatial architecture of Paracoccus sp. biofilm. Biofouling 2010, 26, 449-459. [CrossRef]

54. Foglar, L.; Briški, F. Wastewater denitrification process-The influence of methanol and kinetic analysis. Process Biochem. 2003, 39, 95-103. [CrossRef]

55. Brooksbank, A.M.; Latchford, J.W.; Mudge, S.M. Degradation and modification of fats, oils and grease by commercial microbial supplements. World J. Microbiol. Biotechnol. 2007, 23, 977-985. [CrossRef]

56. Al-Khatib, M.A.; Alam, M.Z.; Shabana, H. Isolation of bacterial strain for biodegradation of fats, oil and grease. Malays. J. Anal. Sci. 2015, 19, 138-143.

57. Teixeira, P.D.; Silva, V.S.; Tenreiro, R. Integrated selection and identification of bacteria from polluted sites for biodegradation of lipids. Int. Microbiol. 2019, 1, 1-14. [CrossRef] 
58. Wang, S.; Shi, W.; Tang, T.; Wang, Y.; Zhi, L.; Lv, J.; Li, J. Function of quorum sensing and cell signaling in the formation of aerobic granular sludge. Rev. Environ. Sci. Bio/Technol. 2017, 16, 1-13. [CrossRef]

59. Rotthauwe, J.H.; Witzel, K.P.; Liesack, W. The ammonia monooxygenase structural gene amoA as a functional marker: Molecular fine-scale analysis of natural ammonia-oxidizing populations. Appl. Environ. Microbiol. 1997, 63, 4704-4712. [CrossRef] [PubMed]

60. Lane, D.J. 16S/23S rRNA sequencing. In Nucleic Acid Techniques in Bacterial Systematics; Stackebrandt, E., Goodfellow, M., Eds.; Wiley: New York, NY, USA, 1991; pp. 205-248.

61. Kloos, K.; Mergel, A.; Rösch, C.; Bothe, H. Denitrification within the genus Azospirillum and other associative bacteria. Aust. J. Plant Physiol. 2001, 28, 991-998. [CrossRef]

62. Throbäck, I.N.; Enwall, K.; Jarvis, Ä.; Hallin, S. Reassessing PCR primers targeting nirS, nirK and nosZ genes for community surveys of denitrifying bacteria with DGGE. FEMS Microbiol. Ecol. 2004, 49, 401-417. [CrossRef]

Publisher's Note: MDPI stays neutral with regard to jurisdictional claims in published maps and institutional affiliations.

(C) 2020 by the authors. Licensee MDPI, Basel, Switzerland. This article is an open access article distributed under the terms and conditions of the Creative Commons Attribution (CC BY) license (http://creativecommons.org/licenses/by/4.0/). 